Тетяна Осіпова

Харківський національний педагогічний університет імені Г. С. Сковороди

Кафедра української мови

ostaniya1967@gmail.com
УДК 811.135.1'27'373.7: 811.511.111'27'373.7:811.162'27'373.7

https://doi.org/10.18485/slavistika.2018.22.2.4

оригинални научни рад

примљено 22.01.2018.

прихваћено за штампу 04.10.2018.

\title{
ОМОВЛЕННЯ НЕВЕРБАЛІКИ ЯК ОЗНАКА НАЦІОНАЛЬНОЇ НАЛЕЖНОСТІ МОВЦЯ
}

\section{(на матеріалі румунської, фінської, серболужицької фразеології)}

У статті встановлено кількісно-пропорційні особливості румунської, фінської та серболужицької фразеології на предмет омовлення невербальних параметрів комунікації, що репрезентують національну комунікативну поведінку етносів, які поєднані спільною територіально-континентальною ознакою, але зберігають власну ментальність в умовах європейського сусідства, окреслено типову належність цих лінгвокультур.

Ключові слова: омовлення невербальних параметрів комунікації, національна комунікативна поведінка, ментальність, тип лінгвокультури.

The article focuses on the analysis of the qualitative, proportional peculiarities of Romanian, Finnish, Serbian-Luzhytska phraseology on the subject of the verbalization of non-verbal parameters of communication, which represent national communicative behavior of the ethnos connected by common territorial characteristics but preserving their mentality in a shared European neighbourhood; the belonging to the above-mentioned linguo-cultures has been characterized.

Key words: verbalization of non-verbal parameters of communication, national communicative behavior, mentality, linguo-culture type.

«Прихована гармонія сильніша за неприховану»

(Геракліт Ефеський)

Глобальні проблеми сучасності торкаються не лише матеріального, але й духовного, культурного світу людини, зокрема збереження культурної спадщини людства з прагматичною метою формування міжкультурної компетенції сучасного мовця, підвищення рівня його комунікативної спроможності, уникнення міжнаціональних конфліктів. Відповідна ціннісна система цілком проектується в лінгвістичну площину, адже “реальний світ” значною мірою підсвідомо будується на основі мовних норм певної етнічної групи (Див. про це: Сепир 1993: 248-258), а кожній мові притаманна «своя особлива метафізика, що окреслює дійсність по-різному тими людьми, які говорять різними мовами. Унаслідок мова репрезентує систему понять для організації досвіду. Нав’язуючи людині певний світогляд, мова зумовлює норми мислення, а відповідно, й поведінки» (Звегинцев 1960: 119) (переклад з рос. автора - Т. О.).

Грунтуючись на лінгвістичних ідеях В. фон Гумбольдта, Ф. Боаса, Л. Вайсгербера, гіпотезі мовної відносності Е. Сепіра-Б. Уорфа сучасні мовознавці визначають міжкультурну компетенцію як ступінь володіння міжкультурною комунікацією, що «з одного боку, передбачає вміння виражати відповідний смисл інтенціонального змісту відповідної мови, а з іншого, - як процес 
взаємної інтерпретації вербальних та невербальних дій мовними особистостями, які наділені пропозиціональними структурами: ментально-особистісними (переконання, цінності, налаштування, схильності, бажання, очікування тощо), когнітивними, лінгвокультурними і под.» (Космеда 2012: 63).

Якщо вербальна компетенція формується внаслідок оволодіння певною «чужою» мовою як засобом спілкування, то невербальна набувається в процесі спілкування з іншим етносом як комунікативний досвід і може відрізнятися або навіть контрастувати $з$ менталітетом мовця.

Зважаючи на національний контекст мислення, підтримуємо думку А. Вежбицької про те, що люди різняться не лише тим, якою мовою вони розмовляють, а ще й тим, що по-різному мислять, відчувають і ставляться до навколишнього світу (див. про це: Wierzbicka 1999), що, власне, й визначає ментальні риси національного характеру. Досить широке й суперечливе розуміння поняття «національний характер» обумовлює вибір матеріалу дослідження. Фразеологічний фонд «найяскравіше виражає етнокультурну специфіку мови, адже в ньому закладений багатовіковий узагальнений досвід усього етносу, особливості його сприйняття світу та самосвідомості, тобто «наївна картина світу». Отже, фразеологічний рівень $є$ пріоритетним у дослідженні культурно детермінованих феноменів» (Мізін 2009: 75)

На сьогодні зроблені спроби встановлення національно-культурної специфіки невербальної комунікації крізь призму фразеології української, білоруської, російської, англійської, німецької мов (А. Акішина, Г. Демиденко, Ж. КраснобаєваЧорна, Г. Крейдлін, В. Маслова, М. Маякіна, Т. Осіпова, А. Рачковська, О. Харчук); $\epsilon$ праці зіставно-порівняльного характеру (Т. Глущенко, І. Микаберидзе, О. Мудра, Н. Смирнова).

Міждисциплінарні підходи розкривають нові можливості вивчення глибинної структури й семантики фразеологічних одиниць, їх типології й функціювання, зокрема актуалізація категорії оцінки як параметра системи національних цінностей сприяє окресленню багатовимірної ціннісної картини світу етносу, а концептуальні методики - укладанню нових моделей концептуального аналізу для встановлення національно-культурної специфіки концепту, репрезентованого фраземами (див. про це: Краснобаєва-Чорна 2016).

Порівняльні дослідження визначають як «важливу форму аналізу зв'язків між способом використання невербальної комунікації та належністю людей до різних культур» (Коццоліно 2015: 34), однак специфіку ментального сприйняття зазвичай розглядають на матеріалі близькоспоріднених (україн. / росій. / білорус. / польськ.) або явно контрастних (україн. / англій. / американ. / француз. / італій. / іспан. / німец.) мовних культур у різноманітних поєднаннях, оминаючи проблеми співіснування ментально різних народів близької локації, що в сучасних міграційних умовах виявляється актуальним із метою запобігання міжкультурних девіацій і конфліктів.

Мета цієї наукової розвідки - з'ясувати кількісно-пропорційні особливості румунської, фінської та серболужицької фразеологій на предмет омовлення невербальних параметрів комунікації, що репрезентують національну комунікативну поведінку етносів, які поєднані спільною територіально-континентальною ознакою, але зберігають власну ментальність в умовах європейського сусідства.

Славистика XXII/2 (2018) 
Мовна й комунікативна компетенція, як відомо, передусім залежить від стереотипів, штампів, кліше, якими володіє мовна особистість. Стереотипи належать свідомості, а в мовленні вони й виявляються у вигляді словесних штампів, кліше, зокрема фразеологізмів, прислів 'їв, приказок, формуючи своєрідне «фразеологічне мислення» (термін Ю. Шевельова) (Осіпова 2010: 7).

Поділяємо думку Т. Космеди, що «вимір ступеня володіння міжкультурною комунікацією, вочевидь, повинен визначатися такими параметрами, як розуміння феноменів реального світу й самого себе в цьому світі крізь призму іншої (...) культури у вигляді сприйняття системи відповідних артефактів матеріальних, розумових, духовних, ціннісних, нормативних та ін., що матеріалізуються, омовлюються знаками (символами) вербальними й невербальними» (Космеда 2012: 63).

Процес вербалізації (омовлення) невербальних знаків становить складне когнітивне явище «подвійного кодування», «у межах якого можливі взаємні переходи, трансляції» (Селіванова 2006: 412), засобом актуалізації внутрішньомовних процесів під впливом так званих інтралінгвальних чинників, що супроводжують мовне спілкування й беруть участь у передачі інформації. «Відбувається, так би мовити, зіткнення двох систем: первинної - мовної, і вторинної - паралінгвальної, (...) згортання структури висловлювання в умовах реального спілкування й аналіз немовних елементів, які є опорою для експліцитного розгортання конкретного висловлювання при сприйнятті повідомлення» (Демиденко 2014: 17). Підгрунтям такого підходу вважаємо одне 3 положень інтроспективної психології В. Вундта про свідомість як сукупність елементів, пов'язаних між собою за принципом асоціації (див. про це: Ярошевский 1987: 25-39).

Незважаючи на сучасні ідеї європейської єдності, що зумовлені процесами глобалізації та взаємоінтеграції, ментальне європейське покриття є досить строкатим і неоднорідним. Мовне розмаїття репрезентує риси національної свідомості народів, які історично проживають на спільному територіальному обширі й мають схожі ціннісні концепти, проте форма, у яку вкладається певний зміст, - своєрідна. Вона відбиває індивідуальний національний досвід. Так, зокрема, ідея любові до Батьківщини може бути актуалізована різними невербальними концептами, порівн.: Своя сторона по шерстке гладит, чужая насупротив (рос.) - проксемний і тактильний; Лучче на свойй стороні кістьми лягти, ніж на чужині слави натягти (укр.) - проксемний і кінетичний; Краще мамалига в рідному селі, ніж сало з хлібом на чужині (румун.) - проксемний $\mathrm{i}$ гастичний; У ріднім краї й каміння вклонясться (фін.) - проксемний і кінетичний; Власна хатка миліша від чужсого палацу (поль.) - проксемний.

Кожний народ має свій набір цінностей і по-різному актуалізує його. Зокрема румунська фразеологія вербалізує всі параметри невербальної комунікації, але 3 відносною нерівномірністю. Так, із 3000 досліджених найбільш поширених паремій 190 омовлюють невербаліку (це становить 6,3% від загальної кількості), а саме: жести й рухи - 25, хода й поза - 9; фізіогноміка, зовнішність - 32; артефакти (одяг, прикраси, предмети) - 27; окулесика - 32; міміка - 8; екстралінгвістика (плач, сміх, шепіт, мовчання і т. ін.) - 27; проксеміка - 14; такесика - 7; хронеміка -1 ; гастика -8 . 
Кінесика (жести й рухи) відображає соціальний досвід румунів, стратегії й тактики в певних комунікативних ситуаціях, порівн.: Не давай шаблі в руки ворогу (РПП : 17); У купия три руки: однію дає, а двома бере (РПП : 45); У попа руки, щцбб брати, а не щзоб давати (РПП : 50); До панів $з$ порожнніми руками нема чого ходити (РПП : 46); Не хрестись, поки не запитав, хто тут святий (РПП : 52); Одна рука хрестить, а друга в чужу пазуху лізе (РПП : 53); Великі об малих ноги витирають (РПП : 42); Багатий чухається, а вбогому здалося, щзо той хоче дати йому баня (РПП : 46); Кинеш палкою в собаку, а попадеш в попа (РПП : 50); На роботі треба повільніше рухати язиком і ивидше руками (РПП : 66) та ін.

Найбільшу групу становлять паремії із компонентом зовнішності людини, причому роль візуалізації полягає у викритті позитивних або негативних внутрішніх ознак і якостей людини, порівн.: Гарний вчинок-як вродлива жсіка (РПП : 25); Чорт, коли старим став, у ченці постригся (РПП : 53); Не кожний, хто з великими вухами, - віслюк (РПП : 74); Як нема вусатого, поцілуєш $i$ иммаркатого (РПП : 90); Дівчину видають заміж чорні брови (РПП : 91); Гарне личко, чорні брови, але в голові полова (РПП : 91); Жінка з гарними очима всіх веселить (РПП : 92); Не боюся чоловіка низького зросту, аби лиш глузду в нім було доста (РПП : 93); У Драгашанах і святі з червоними носами (РПП : 140) (Драгашани - центр виноробного району в Румуніï); У Бухаресті й собаки на хвостах бублики носять (РПП : 169) і т. ін.

Таку ж важливу роль у спілкуванні відіграють оптичні параметри, зокрема погляд як контактовстановлювальний та оцінювальний засіб, порівн.: Дивиться на бога, як курка, коли п'є воду (РПП : 49); Піп одним оком на сало, а другим на борошно дивиться (РПП : 51); Піп очі залив, а Іван і не куштував (РПП : 51); Очі на іконі, а на думці - пані (РПП : 52); Очі розсудливого бачать далі (РПП : 78); У чоловіка очі, щңоб дивитися, а в жінки, щцоб на неї дивилися (РПП : 87); Мертвих позбавляють очей круки, живих - підлабузники (РПП : 124); Ти йому оком моргнеш, а він тобі головою кивас (РПП : 219); 3 брехнею пообідаєш, а до вечері очі на лоба повилазять (РПП : 134); В очі-одне, заочі-інше (РПП : 111) та ін.

Одним з необхідних складників успішної комунікації румуни вважають предметну сферу, зокрема наявність артефактів (одяг, прикраси, предмети), порівн.: Часто будеш святкувати, не буде чого вдягати (РПП : 49); У нього хрест на грудях і чорт у серизі (РПП : 50); Одягнувши рясу, чинцеем не станеш (РПП : 53); Розумній голові й подерта шапка личить (РПП : 72); Не довіряє навіть свойй сорочці (РПП : 143); Жупан одягає, а розуму не має (РПП : 146); Позичений одяг не гріє (РПП : 216) та ін.

Паремійний контент фінського етносу містить 7,5 \% (153 з 2000) таких одиниць, що омовлюють невербальні параметри, зокрема жести й рухи - 16, хода й поза - 11; фізіогноміка, зовнішність - 18; артефакти (одяг, прикраси, предмети) - 9; окулесика - 17; міміка - 6; екстралінгвістика (плач, сміх, шепіт, мовчання і т. ін.) - 22; проксеміка - 17; такесика - 10; хронеміка - 3; гастика -17 . Виокремлюємо й паремії, що позначають вдачу, манеру спілкування - 6.

Найбільшу кількісну групу становить екстралінгвістика (плач, сміх, шепіт, мовчання і т. ін.), виступаючи маркером статусності, характеру і вдачі, гендер- 
них та вікових особливостей людини, порівн.: Бідний має право на сльози, багатий - на забави (ФПП : 26); Бідний у багатого заговорить, і то крізь сльози (ФПП : 27); Голодному не до сміху (ФПП : 37); Одинак довго не сміється (ФПП : 76); Весело парубкувати, та гірко холостякувати: без жінки й кішка не нявкає, і діти не плачуть (ФПП : 77) - омовлюється статусний параметр; Ледачий пітніє, коли їсть (ФПП : 64); Дурний і з нісенітниці регоче (ФПП : 108); Село горить - божевільний регоче (ФПП : 109); Із горлечка п'єய - плакатиме шия! (ФПП : 106) - оцінка негативних рис людської вдачі; Поганий чоловік із сонька, погана жінка з реготухи (ФПП : 73); Вітер стихне, коли дощ лине; жінка пересердиться, коли розплачеться (ФПП : 73); Східний вітер приносить дощ, сварка - жіночі сльози (ФПП : 73) - омовлення гендерних параметрів; «Кахи-кахи», - старечий сміх (ФПП : 91) - вікових; I бог сміється, коли злодій у злодія иупить (ФПП : 101); Камінь $і$ від горя не плаче (ФПП : 122); Плачем від смерті не відбудешся (ФПП : 92); Море сліз не відчуває (ФПП : 126); Сміх продовжує вік (ФПП : 156) - репрезентація вольових якостей національного характеру.

Проксеміка у фінів відіграє не останню роль передусім як параметр організації простору, порівн.: Господиня у воротях помітна (ФПП : 72); Коли біда в xami, допомога в сінях (ФПП : 69); Де-де, а біля казана люд збереться (ФПП : 90); Дитина тягнеться до води, старий - до вогню (ФПП : 91); Влітку проживеш і край поля (ФПП : 116); Через річку по воду не ходять (ФПП : 124), а також як чинник, що впливає на спілкування, порівн.: Рідко вовк перед вівцею звертас з дороги (ФПП : 27); П'ятеро голодних лежсать, шостому ніде сісти (ФПП : 36); Біду коло воріт не очікують (ФПП : 43); Ледача шкапа до будьяких воріт повертає (ФПП : 66); Дорослий є дорослий, хоч і на припічку сидить (ФПП : 84); Господар до роботи - гість у дорогу (ФПП : 89); 3-за спини великого добре огризатися (ФПП : 97); Хто не дивиться вперед, хай пильнуе ззаду (ФПП : 100); Узяв дурня в човен-тримайся берега (ФПП : 110) та ін.

Як виявилося, паремії з компонентами гастики не лише ілюструють смакові уподобання фінів, але й виражають соціально-особистісні риси комунікантів, порівн.: Солоне й густе - біднякові ласощі (ФПП : 35); Молоко і каша - їжа багатія, салака й хліб - торпаря (ФПП : 35); Сіль - біднякова закуска (ФПП : 38); Той хвалить вівсяний хліб, хто не куштував житнього (ФПП : 51); Чужий хліб гіркий, хоч і маслом намаж (ФПП : 51); У кого ноги в гною, у того губи в салі (ФПП : 56); У кого гороховий суп, у того й тютюн (ФПП : 88); Сон $і$ ї̈са - солодкі, робота - гірка (ФПП : 144); Що то за кухар, щзо й не лизне! (ФПП : 63); У вдівия холодний пиріг (ФПП : 77); Дурний тамує спрагу кашею, божевільний - тістом (109) - омовлення соціально-статусного параметру; Кава без цукру й почілунок безбородого не смачні (ФПП : 81); Сіль - ̈̈жі честь (ФПП : 87); Вино не п'ють, а смакують (ФПП : 106); Вино звеселяє, пиво додає сили (ФПП : 89) - репрезентація смакових уподобань; Дай притулок подорожньому, а хліба - гостеві (ФПП : 90); Риб'ячу голову -синові, хвіст - доньці (ФПП : 87); Скупий наӥдається в гостях (ФПП : 102); Слухати можна й не обідавши (ФПП : 147) - репрезентація етичних норм фінського етносу.

Зазначимо, що мовчання, на відміну від інших європейських етносів, у фінів репрезентовано незначною кількістю одиниць, порівн.: Коли дурний мовчить, 
то він мудрий (ФПП : 107); Мовчун усе здолае (ФПП : 146); Розумний мовчить (ФПП : 146) омовлення загальнонаціональної оцінки стратегії мовчання; Немовлене слово в роті пече (ФПП : 148) - вияв експресивності; Про поганого пліткують, про хорошого співають, а про середняка - ні слова (ФПП : 147) репрезентація комунікативного стереотипу.

Омовлення параметру зовнішності у фінських пареміях скероване більше в соціальну, ніж в естетичну сферу, порівн.: Багатія завидки беруть, коли в бідняка щцки пашать (ФПП : 27); Бідняк низенький $і$ на пеньку (ФПП : 27); Бородатий схожий на цапа, безбородий - на пастора (ФПП : 47); Не всі ковалі, в кого очі чорні (ФПП : 61); На морі або золото в кищеню, або пісок у ніздрі (ФПП : 127) (ти або багач, або мрець) - омовлення соціального статусу; Ледар $i$ влітку не засмагає (ФПП : 64); Ледар і надвечір бадьорий (ФПП : 64); У гордого бика великі роги (ФПП : 98); Сердитий і вві сні бородою трясе (ФПП : 104); Рідкозубий - брехливий (ФПП : 154); Поганому погане й личить (ФПП : 100); Мудрість прийде, як борода виросте (ФПП : 97) - репрезентація людської вдачі; Дівоче личко - для сватів (ФПП : 77); Окраса чоловіка - борода, окраса жінки-довга коса (ФПП : 80); Смаглявого милом не відмиєщ (ФПП : 70); Маленькі чоловіки $\epsilon$, а бородатих дітей не стрінеш (ФПП : 84); По рогах судять про корову, по зубах - про коня (ФПП : 137) - вербалізація гендерних уявлень.

Як відомо з історії, не всім європейським етносам вдалося набути статусу державності, і вони існують у складі інших держав у статусі національних меншин. Це стосується серболужицького етносу, який входить до складу мешканців Німеччини. Незважаючи на різну належність до мовних сімей (німецька - романська група мов, серболужицька - слов'янська), багатовіковий добросусідський досвід сприяв збереженню мови й культури серболужичан, хоч на ментальному рівні спостерігаємо часткову асиміляцію.

Емпіричний розподіл серболужицьких паремій з невербальним компонентом відбувається відповідно до таких пропорцій: із 2000 опрацьованих одиниць виокремлено лише 63 таких, що омовлюють невербаліку (3,1 \%), зокрема: жести й рухи -9 , хода й поза -4 ; фізіогноміка, зовнішність - 9; артефакти (одяг, прикраси, предмети) - 4; окулесика - 11; міміка - 3; екстралінгвістика (плач, сміх, шепіт, мовчання і т. ін.) - 11; проксеміка -1 ; такесика -5 ; хронеміка -0 ; гастика -6 .

Серед них найбільші кількісно - групи паремій з параметрами окулесики та екстралінгвістики. Окулесика репрезентована одиницями, що характеризують комунікантів засобом омовлення погляду, порівн.: Хазяїн бачить одним оком більше, ніж наймит двома (СПП : 34); Вуха вірять чужій губі, очі вірять самі собі (СПП : 63); Дівчата пишаються, хлопці витріщаються (СПП : 58); Милосердні очка для сумних є щедрими зірками (СПП : 59); Щічки і вічки жениха ловлять (СПП : 59); Часом око більше скаже, ніж язик (СПП : 88); Продавець потребує губів, а покупець - очей (СПП : 90); Ласкава кішка фальшиві очі (СПП : 112), або пропонують певні комунікативні стратегії, порівн.: Дивись не на очі зажери, а на його кігті (СПП : 80); Купуй очима, а не вушима (СПП : 89); Ліпше сказати в очі, ніж позаочі вуха мозолити (СПП : 109). 
Паремії з екстралінгвальним параметром репрезентують різноманітні комунікативні тактики, зокрема: Голодний живіт не має вух (СПП : 35); Сміх $i$ плач з одного мішка (СПП : 41); Ліпше, щуоб діти від батька плакали, ніж мав би він потім - від них (СПП : 55); Іззовні солодкий сміх, зсередини - згірклий гріх (СПП : 64); Охриплого не змушуй співати (СПП : 72); Добра рука охоче іншим сльози витирає (СПП : 81); Довга казань ізрання - самі позіхання (СПП : 94); Не дмухай на вогонь - волосся обсмалиш (СПП : 95); Коли пси гризуться, то вовки сміються (СПП : 113); Голосне кудахтання - дрібне яєчко (СПП : 121).

Зовнішність для серболужичан - це не лише естетика, порівн.: Чим гарніша корчмарка, тим смачніше пиво (СПП : 45); Файного личка родимка не псує (СПП : 58); Щічки і вічки жениха ловлять (СПП : 59), але й певний параметр диференціації комунікантів за різними особистісними ознаками, порівн.: У багатої дівчини й горба не побачать (СПП : 34); Борода довга, хоч вузли в'яжи, а розум короткий (СПП : 37); Вдає з себе мудрого, а під носом - мокро (СПП : 40); Горбатому свого горба не видно (СПП : 42); У бабія голова й полисіє, а не помудрішає (СПП : 57); На носі рум'янець - горілчаний напис у п'яниць (СПП : 98); Безбородий з бородатим перевернуть хату (СПП : 125) та ін.

Група жестових паремій репрезентує комунікативні тактики, порівн.: Коли тебе мучать - покажи кулак (СПП : 95); Допомога мусить мати швидкі ноги й руки (СПП : 83), стратегії, порівн.: Працьовиту руку вітають і серби, і німиі (СПП : 19); Догодлива рука більш дістає, ніж просить (СПП : 89); На непокірну спину - стусани без упину (СПП : 33), оцінки, порівн.: Кулачище найдурніше по столі б'є найгучніше (СПП : 38); Хто медовим пальцем тобі губи маже - задумує враже (СПП : 63); Зажерливий рот -хапка рука (СПП : 42); Краще рука, щцо дарує, аніж губа, щзо изілує (СПП : 65) та ін.

Отже, найбільший відсоток омовлення невербаліки спостерігаємо у фінській фразеології (7,5 \%) із актуалізацією передусім екстралінгвальних, просторових, смакових та оптичних (зовнішність комуніканта) параметрів, що моделюють процеси спілкування, обгрунтовують їхній характер. Невербаліка фінів раціональна, насичена, із вираженим оцінним компонентом. Візуалізація внутрішніх якостей комунікантів засобом омовлення зовнішності, вербалізація смакових параметрів як етнічних уподобань та соціальних можливостей, кодифікація статусності, характеру і вдачі, гендерних та вікових особливостей людини - усе це свідчить про високий імплікаційний рівень фінської лінгвокультури, що наближає іiї до ширококонтекстних типів (за Е. Холлом), у яких інформація експлікується з урахуванням найширшого культурологічного й найближчого ситуативного контексту.

Невербальний потенціал румунської фразеології дещо менший (6,3%); омовлюються більшою мірою оптичні параметри (фізіогноміка, зовнішність, власне окулесика, артефакти), а також кінесика та екстралінгвальні чинники. На відміну від фінів, проксеміка й гастика в румунів не вияскравлюється. Характерною особливістю румунської фразеології з невербальним компонентом є репрезентація типових комунікативних ситуацій, прописування їхніх стратегій і тактик, зовнішності людини й ролі артефактів (переважно одягу) у комунікації відповідно до шкали оцінювання, що надає можливість експлікувати позитивні або негативні внутрішні ознаки та якості. Такий розподіл долучає румунську фразеологію до так званого «проміжного» типу лінгвокультури, де врівноважуються 
ролі вербального й невербального, а перевага у вербалізації оптичних параметрів ілюструє емоційність та експресивність національної вдачі.

Найменший відсоток омовлення невербаліки спостерігаємо в серболужицьких пареміях ( $3,1 \%)$. Широко репрезентований зоровий контакт (окулесика), багата палітра екстралінгвальних чинників, увага етносу до параметру зовнішності, що називають супровідними, паралінгвальними засобами, визначають пріоритетність вербального у спілкуванні. Окрім того, група паремій вербалізує конкретні комунікативні стратегії або тактики, що реалізується у вигляді паремійних імперативів, формуючи певний арсенал комунікативних приписів у конкретних ситуаціях, що також позиціонує перевагу вербального у спілкуванні.

Отже, зважаючи на наслідки невербального профілювання серболужицької фразеології, можемо констатувати ознаки вузькоконтекстності зазначеної лінгвокультури, що виявляється в перевазі експліцитного над імпліцитним і мотивується впливом лінгвокультури основного етносу держави, до складу якої входить серболужицька національна меншина.

Невербальне профілювання фразеологічного матеріалу дає можливість виявити типологічні особливості певної лінгвокультури, специфіку національної комунікативної поведінки, а також з'ясувати пріоритети, що переважають у спілкуванні того чи того етносу, збагатити міжкультурний комунікативний досвід. Наукова розвідка має перспективи, що полягають у поглибленні дослідницької методики й розширенні дослідницьких аспектів.

\section{Лimepamypa}

Демиденко, Г. Г. Паралінгвальні фразеологізми в українській етнокультурі: дис. ... канд. філол. наук: спец. 10.02.01 - українська мова. Харків, 2014.

Звегинцев, В. А. Теоретико-лингвистические предпосылки гипотезы СепираУорфа. [В:] Новое в лингвистике. Вып. 1. Москва: Прогресс, 1960: 111-134.

Космеда, T. A. Ego i Alter Ego Tapaca Шевченка в комунікативному просторі щоденникового дискурсу. Дрогобич: Коло, 2012.

Коццолино, М. Невербальная коммуникация. Теории, функции, язык и знак. 2-е изд. испр. Пер. с итал. Харьков: Изд-во «Гуманитарный Центр», 2015.

Краснобаєва-Чорна, Ж. В. Лінгвофраземна аксіологія: парадигмально-категорійний вимір: монографія. 2-е вид., випр. і доп. Вінниця: Нілан-ЛТД, 2016.

Мізін, К. І. Перспектива вивчення антропоцентричності усталених порівнянь (на матеріалі компаративних фразеологій англійської, німецької, української та російської мов) [В:] Лінгвістика: зб. наук. пр. Луганськ, 2009. №1 (16): 75 -81.

Осіпова, Т. Ф. Параметри вербальної і невербальної комунікації в українських пареміях: дис. ... канд. філол. наук: спец. 10.02.01 - українська мова. Харків, 2010.

Селіванова, О. Сучасна лінгвістика: термінологічна енциклопедія. Полтава: Довкілля-Д, 2006.

Сепир, Э. Избранные труды по языкознанию и культурологии. Москва: Прогресс, 1993: 248-258.

Шевельов, Ю. О. О. Потебня і стандарт української літературної мови. [В:] Мовознавство. 1992. № 2: 67-74; № 3: 57-68.

Славистика XXII/2 (2018) 
Ярошевский, М. Р. Категориальный аппарат психологии [В:] Хрестоматия по психологии (под ред. А. В. Петровского). Москва: Просвещение, 1987: 25-39.

Wierzbicka, A. Emotions Across Languages and Cultures. Diversity and Universals. Cambridge University Press, 1999.

\section{Джерела}

РПП: Румунські прислів'я та приказки (перекл., упоряд., В. Семчинського). Київ: Вид-во «Дніпро», 1978. («Мудрість народна»)

СПП: Серболужицькі прислів'я та приказки (упор. К. Трофимовича; пер. $з$ серболуж. В. Лучука) Київ: Вид-во «Дніпро», 1988. («Мудрість народна», зб. 46)

ФПП: Фінськіприслів'я таприказки (перекл., упоряд., вст. слово О. Завгороднього). Київ: Вид-во «Дніпро», 1981. («Мудрість народна», зб. 32)

Proverbe românești: https://ro.wikiquote.org/wiki/Proverbe_rom\%C3\%A2ne\%C8\% 99tit\#N

Serbian proverbs: https://en.wikiquote.org/wiki/Serbian_proverbs

Suomalaisia sananlaskuja: https://fi.wikiquote.org/wiki/Suomalaisia sananlaskuja

\section{Тетјана Осипова}

\section{ВЕРБАЛИЗАЦИЈА НЕВЕРБАЛНЕ КОМУНИКАЦИЈЕ КАО ИЗРАЗ ГОВОРНИКОВЕ НАЦИОНАЛНЕ ПРИПАДНОСТИ}

(на грађи румунске, финске и лужичкосрпске фразеологије)

\section{Резиме}

Полазећи од лингвистичких идеја В. фон Хумболта, Ф. Боаса, Л. Вајсбергера, као и од Сапир-Ворфове хипотезе језичке релативности, савремени лингвисти одређују интеркултуралну компетенцију као степен владања интеркултуралном комуникацијом. Вербална компетенција се формира као последица владања одређеним нематерњим језиком као комуникацијским средством, док се невербална стиче као комуникативно искуство у процесу комуникације са представницима другог етноса и може да се разликује, чак и да одудара, од говорниковог менталитета.

Специфичне одлике менталне рецепције обично се разматрају на грађи блискосродних или веома удаљених језичких култура без потенцирања питања коегзистенције локацијски блиских али ментално различитих народа, што се у савременим условима интензивних миграција испоставља као актуелан проблем, чије проучавање може допринети спречавању интеркултуралних девијација и конфликата.

У раду се разматрају специфичне црте румунске, финске и лужичкосрпске фразеологије у вези са вербализацијом невербалних параметара комуникације етноса који постоје на истој територији, али чувају оригиналан менталитет у условима европског суседства.

Кључне речи: интеркултурална компетенција, интеркултурална комуникација, вербална и невербална комуникација, ментална рецепција, комуникативно понашање етноса, невербални вредносни концепт, визуализација, импликација, експликација, вербализација невербалних параметара комуникације. 